us a copy of the reproduction. Mr. Hewitt, in 1925, used Autochrome plates specially sensitized by himself, and his camera had a focal length of $3 \mathrm{ft}$. Dr. Gardner, in 1936, used Dufay colour plates and a camera of $19-\mathrm{ft}$. focal length. Owing to the greatly differing circumstances, any detailed comparison of the two pictures would be invidious. The picture $\mathrm{Mr}$. Hewitt has sent us is about a tenfold enlargement of the original, and shows a yellow coronal image extending to about a fifth of a solar radius from the limb, so that on the original plate the coronal image can only have been about $0.6 \mathrm{~mm}$. across, whereas Dr. Gardner's picture was reproduced at about actual size and showed a corona extending to about a solar radius or about $20 \mathrm{~mm}$. on the original plate. In view of the low resolving power of colour plates, it would be absurd to expect much recognizable detail on the 1925 plates, and indeed there is only a suggestion of coronal form, and the colour is presumably in error, but the photographs had the value of demonstrating that colour plates could be made sensitive enough to photograph a total eclipse.

\section{Plant Diseases and Pests of India}

Science and Culture contains an interesting review of "Some Plant Diseases and Pests of India and their Control" by Amil Mitra (2, Nos. 8 and 9, Feb. and March 1937). The paper should serve the useful purpose of directing attention to the serious nature of plant disease, for it includes succinct references to the monetary or percentage losses occasioned by many fungi and insect pests. These are sufficiently convincing. The world's loss through the activities of various rust diseases of wheat is estimated at about $£ 60,000,000$, and India bears about $£ 4,000,000$ of this. A smut disease of the Jowar crop, caused by the fungus Sphacelotheca sorghi, causes a loss of 20-25 per cent, and in the Bombay Presidency alone, this means a cost of two crores of rupees (about $£ 2,000,000$ ). Sugar cane mosaic, caused by a virus, often lowers the yield of sugar by 30-35 per cent, whilst a wilt of the pea crop caused by the fungus Fusarium Vasinfectum seems to cause the highest percentage damage, for more than half the crop is often lost as a result of its depredations. The review mentions the particular methods of control for each disease or pest, which have been found most effective in practice. A few insect and eelworm enemies are mentioned, but the main emphasis of the paper is that of a mycologist.

\section{Journal of Parapsychology}

AN introduction by Prof. Wm. McDougall gives reasons for the publication of a new journal, the Journal of Parapsychology, and making clear its object. Throughout the ages, people have asked: Are mental processes always and everywhere dependent upon material and physical organizations ? What are the relations of mind and matter? Do the volitions and beliefs of men make any difference to the historical course of the events of the world? Is the physical co-extensive with the mental and the powers and potentialities of mind to be defined by the laws of the physical sciences? For the most part, the psychology studied in the universities has not concerned itself experimentally with these problems, and such work as has been undertaken has generally been the leisure-time pursuit of interested amateurs. Prof. McDougall thinks that all those phenomena vaguely denoted by the phrase, 'psychical research', ought to be the study of trained scientific workers in the universities, both in the interests of the development of knowledge and of the public. A beginning was made at Duke University in 1930 to study what the researchers called 'extrasensory' perception. In order that the experiments made in one laboratory may be repeated by other workers, it seemed desirable that there should be a journal. The need for multiple repetitions by different observers of all experiments purporting to give positive results is greater in this field than in others. The word parapsychology is chosen to denote the more strictly experimental part of psychical research. The journal is published quarterly, and the first number is dated March 1937 (Durham, N.C. : Duke University Press. Subscription 3 dollars a year).

\section{Cist Burial at Blaydon-on-Tyne}

AN interesting example of a cist burial is reported from Blaydon-on-Tyne (The Times, Aug. 6). The discovery was made by workmen digging in a sandpit, who uncovered the broken upper slab of the chamber. The dimensions of the cist were $3 \mathrm{ft} .8 \mathrm{in}$. in length, $2 \mathrm{ft} .3 \mathrm{in}$. wide and about two feet in depth. The interior was filled with sand, but among the contents were found a human skull and bones of the skeleton. With them was a flint knife about two inches in length. The site was visited and the cist examined by Miss G. M. Scott, assistant curator of the Hancock Museum, Newcastle, Mr. W. Bulmer, of the Corbridge Museum, and other authorities of the locality, in whose opinion the find belongs to the Bronze Age and is to be assigned, notwithstanding the absence of the beaker which might be expected, to a date at about 1500 B.c. A burial with skeletal remains of a somewhat earlier date was found on Summerhill, not far away, seven years ago and is on view as reconstructed in the Hancock Museum.

\section{National Museums of Natural History}

Frequent visits from, and even interchange of, the staffs of the larger museums of the British commonwealth of nations, as referred to in an article in NATURE of January 9, has evidently the strong approval of Mr. Frederick Chapman, the well-known authority on the Foraminifera, who has written to us from Melbourne on the subject. The 'Australian Museum' is situated at Sydney and there is the 'Melbourne National Museum', which from the wealth of its collections, especially palæontological, must be regarded as also of the highest rank. It is immaterial that one museum may be richer than the other in some sides of biology, for such must always be the case. The important matter is that tightening of the bonds between all the museums in question, which has the approval of the Museum Association 
of Australia. Further, we understand that a representative of this Association was deputed to discuss this with the trustees of the British Museum this summer. When can we expect to hear the result of this discussion?

\section{Research at Armstrong College}

From Armstrong College, Newcastle-upon-Tyne, we have received a report for 1935-36, somewhat belated, by the Standing Committee for Research. The importance of some of the work accomplished with the help of the Committee's small subventions (twenty-six grants amounting in the aggregate to $£ 846$ ) is well brought out in an eighteen-page summary prefixed to the individual reports of the recipients and list of publications. An obvious advantage of a fund such as that administered by the Committee, unappropriated in advance to specified fields, is that its administration compels representatives of different departments to take an interest in research in each other's fields, and this promotes inter-departmental collaboration in research, instances of which are cited in the report. Of the role of philosophy in the University, the Committee takes a liberal view, for it refers to works emanating from the College's Department of Philosophy as "original contributions towards the formation of that background of knowledge which forms, or should form, the background of university education".

\section{American Documentation Institute}

The American Documentation Institute was incorporated at a meeting in Washington on March 13 as a corporation "not for profit" but for educational, literary and scientific purposes. The first objective of the new organization is to develop and apply the new technique of microphotography to library, scientific and other material. This national organization was foreseen as an outline of the documentation activities of Science Service when they commenced in July 1935. Bibliofilm Service has been conducted by Science Service in co-operation with the Library of the U.S. Department of Agriculture as a service to research workers, and in auxiliary publication through microfilm, leading academic and scientific journals have co-operated.

\section{Cytological Technique}

A SHORT but useful pamphlet giving an "Outline of Cytological Technique for Plant Breeders" is issued by the Imperial Bureau of Plant Genetics (1s. 6d.). Genetics and cytology have become so intimately interwoven in their results that every plant breeder needs to have some knowledge not only of chromosome investigations but also of the methods of cytology. The various techniques involved are sufficiently exacting if satisfactory results are to be obtained. This pamphlet gives an account of the paraffin method, the smear method and a short statement containing the essentials of technique in the use of the microscope, the methods being based mainly on the schedules in use at the John Innes Horticultural Institution, Merton.

\section{Microscopy: the Quekett Microscopical Club}

Watson's Microscope Record of May (No. 41), among other matter, contains an account by $\mathrm{Mr}$. J. F. Stirling of the microscope used by John Dalton, now in the possession of the Manchester Literary and Philosophical Society, and an article by the editor on the appropriate eyepiece to use with certain objectives. Two new species of Bdelloid Rotatoria are described by Mr. W. E. Garner in the Journal of the Quekett Microscopical Club of April (Ser. 3, 1, No. 7, p. 280). Mr. W. E. Watson Baker is the new president of the Quekett Club, which is holding its annual conversazione on October 12 in the rooms of the Royal Society at Burlington House.

\section{Conference on Protection against Natural Disasters}

THE first "Conférence internationale pour la protection contre les calamités naturelles" is to be held at the Paris Exhibition on September 13-17. The following titles of sections of the Conference indicate its scope: vulcanology and seismology, meteorology, zoology and epidemiology, economic and social crises (fires, famines), assurances. The organizers of the Conference are the Commission Française d'études des calamités, one of a dozen such national com. missions which owe their existence to the initiative of the editorial board of the scientific periodical, Matériaux pour l'étude des calamités, established in 1924 by M. Raoul Montandon. In that year the Italian commission was formed. Its president is Giovanni Ciraolo, who is also president of the Union internationale de secours founded by the League of Nations in 1927, when the French commission was formed. Later, similar bodies were established in Austria, Belgium, Bulgaria, Chile, Czechoslovakia. Greece, Hungary, Italy and Switzerland. Others are in course of formation in Russia and Yugoslavia. The opening session will be presided over by the Under-Secretary of State for Scientific Researches and the closing session (to be followed by a reception at the Hôtel de Ville and a banquet) by the Minister for the Colonies. Admission to membership of the Conference involves payment of a fee of 100 francs, exclusive of the charge of 40 franes for participation in the banquet. Membership will carry the right of free entry to the Exhibition during the Conference. The address of the secretariat is : Laboratory of Applied Entomology, 45 bis, rue de Buffon, Paris, $5^{\mathrm{e}}$. The secretariat will, if desired, reserve bedrooms for members.

\section{Comet Finsler}

Predrction for the place of Finsler's Comet for the next three weeks is given in Announcement Card No. 421 issued by Harvard College Observatory. The ephemeris is based on a parabolic orbit computed by Dr. A. D. Maxwell of the University of Michigan. The time of deduced perihelion passage is August 15.76946 U.T. This comet was discovered on July 4 last by Finsler at Zurich; it was then of the 7 th magnitude. It is now possible to locate the comet with the naked eye. The following predicted positions at $0^{\text {h }}$ U.T. show that the comet will pass $3^{\circ}$ or $4^{\circ}$ 